\title{
COMMENT
}

\section{Measuring predation with tethering experiments}

\author{
Richard B. Aronson*, Kenneth L. Heck Jr, John F. Valentine \\ Dauphin Island Sea Lab, 101 Bienville Boulevard, Dauphin Island, Alabama 36528, USA \\ and \\ Department of Marine Sciences, University of South Alabama, Mobile, Alabama 36688, USA
}

Benthic ecologists employ a variety of experimental protocols to measure pattern and process in marine communities. Each method has its strengths and weaknesses, and the weaknesses in particular must be understood if results are to be interpreted correctly. For example, while mesocosm studies allow researchers to manipulate biological interactions in ways that would be impossible in the field, such studies have been criticized for a lack of realism, replicability, and repeatability through time (Kraufvelin 1999). Tethering experiments have also been criticized because they may introduce artifacts that confound their interpretation (Peterson \& Black 1994). In response, it has been argued that such artifacts are usually minor (or nonexistent; Pile et al. 1996) and do not negate the value of tethering as a comparative measure of predation potential, which is defined as the rate at which the prey of interest would be consumed were they readily available to predators (Aronson 1989, Aronson \& Heck 1995).

Kneib \& Scheele (2000) tested the utility of tethering by comparing the mortality of tethered and untethered ('free') grass shrimp Palaeomonetes pugio in the face of varying densities of a predatory fish, the mummichog Fundulus heteroclitus. Three tethered and 27 untethered grass shrimp were placed in 761 mesocosms and exposed to $0,1,2,4,8$, or 16 mummichogs for $3 \mathrm{~h}$. The results were analyzed by 2-way ANOVA, with tethering treatment (tethered vs free) and predator density as fixed factors. Kneib \& Scheele (2000) found significantly greater proportional mortality of tethered than free individuals. There was a significant effect of predator density and a significant interaction between tethering treatment and predator density. The significant interaction reflected the fact that the survivorship of tethered shrimp declined more steeply as a function of predator density than did the survivorship of free shrimp. Kneib \& Scheele (2000) also monitored the survivorship of the tethered prey through

\footnotetext{
*E-mail: raronson@jaguar1.usouthal.edu
}

time during their experiments. They found a significant interaction between predator density and exposure time, which may have reflected a decline in the feeding efficiency of the predators when they were present at high densities in the mesocosm. Kneib \& Scheele (2000) concluded from these results that tethering cannot be used as even a relative measure of predation potential, because the relationship between relative loss rates of tethered and free shrimp changed across a gradient of predation potential...'

The authors suggested that tethering experiments are not particularly informative, except in the grossest sorts of comparisons between habitats with very low and very high densities of predators. If the latter suggestion is correct, then Aronson's (1989) use of tethering to measure the predation potential experienced by ophiuroids, for example, may have succeeded because he compared habitats with many, fast-moving predators to habitats with few, slow-moving predators. The escape responses of prey must also be taken into account; prey that remain quiescent on the bottom, such as ophiuroids (Aronson 1988), are probably more appropriate for tethering experiments than highly mobile prey with rapid escape responses, such as some fish, crabs, and shrimp (Shulman 1985, Zimmer-Faust et al. 1994, Kneib \& Scheele 2000).

Kneib \& Scheele's (2000) criticisms of tethering methodology may be valid for the taxa tested, and they are certainly worth serious consideration. Whether or not Kneib \& Scheele (2000) are correct, the study that forms the basis of their conclusions is itself highly problematic. Even ignoring the problems inherent in mesocosm studies (Kraufvelin 1999), their experimental design is flawed.

First, the use of only 3 tethered grass shrimp per experimental trial along with 27 free grass shrimp created a problem of statistical continuity. Each tethered shrimp killed in an experimental trial reduced the overall survivorship of tethered shrimp in that trial by $33 \%$. In contrast, each free shrimp killed reduced the overall survivorship of free shrimp by $3.7 \%$. The differ- 
ence in the denominators used to calculate survivorship artificially inflated the proportional influence of each predation event on a tethered shrimp. The result was an increased probability of making a type I error in calculating the interaction (i.e., it increased the probability of erroneously concluding that there was a significant interaction when in fact there was not).

Kneib \& Scheele (2000) justified the unequal sample sizes by stating, 'Free prey were many times more abundant that tethered individuals in our experiment, as might be expected under field conditions.' This rationale misses the point, however, because the purpose of Kneib \& Scheele's (2000) mesocosm experiment was completely different from the purpose of tethering experiments in the field. The goal of a field experiment would be to compare the mortality of tethered prey among treatments with equal sample sizes of tethered prey, not to compare the mortality of tethered and untethered prey as in Kneib \& Scheele's (2000) mesocosm experiment.

Second, the 2 treatments of the tethering factor, tethered and free, were measured at the same time in the same mesocosms with the same predators. This means that the survivorship data for tethered and free shrimp were non-independent, further confounding interpretation of the significant interaction between tethering treatment and predator density. The lack of independence of the treatments invalidates the ANOVA. Although naturally occurring predators in a field situation would be expected to eat both tethered and untethered prey, it bears repeating that field experiments only measure consumption of the tethered prey in the different treatments.

Third, the experiments were limited to an artificially simplified, one-step food chain. Had a third trophic level-piscivorous fish - been included in the mesocosm study, it is likely that the mummichogs would have foraged in a risk-averse manner, as they presumably would have done in a tethering experiment conducted in the field. Such a change in foraging behavior might have had a substantial effect on patterns of mortality in the grass shrimp. Because of these statistical and methodological problems, this study cannot be used to draw firm conclusions about tethering one way or the other.

Aronson \& Heck (1995) suggested that, despite their potential problems, tethering experiments can be profitably combined with other types of studies to improve our understanding of predation in benthic communities. We support the idea of continuing to examine the validity of this assertion, especially since an earlier controversy over tethering substantially improved the way coral reef ecology is done. Steneck (1983) showed in a field study that tethering blades of the seagrass Thalassia testudinum on coral reefs gave estimates of herbivory potential that were inconsistent with a variety of other measures. Steneck's (1983) results, along with other observations on the limitations of the method (Hay 1984), led to a more realistic interpretation of the 'Thalassia bioassay' (e.g., Lewis 1986). Tethering experiments surely provide information about predation. As Kneib \& Scheele (2000) point out, however, further experimental studies are necessary to judge the accuracy with which tethering results reflect natural patterns of predation potential for particular combinations of predators and prey.

Acknowledgements. The research that led to this paper was funded by the National Undersea Research Center at the University of North Carolina, Wilmington (grant UNCW-9537 to J.F.V. and K.L.H.), and by the Alabama Center for Estuarine Studies, a program of the US Environmental Protection Agency. Additional support was derived from the US National Science Foundation (NSF grant OPP-9908828 to R.B.A.). Comments from 2 anonymous reviewers helped us better articulate some of our points. This is Contribution No. 324 from the Dauphin Island Sea Lab.

\section{LITERATURE CITED}

Aronson RB (1988) Palatability of five Caribbean ophiuroids. Bull Mar Sci 43:93-97

Aronson RB (1989) Brittlestar beds: low-predation anachronisms in the British Isles. Ecology 70:856-865

Aronson RB, Heck KL Jr (1995) Tethering experiments and hypothesis-testing in ecology. Mar Ecol Prog Ser 121: 307-309

Hay ME (1984) Patterns of fish and urchin grazing of Caribean coral reefs: are previous results typical? Ecology 65:446-454

Kneib RT, Scheele CEH (2000) Does tethering of mobile prey measure relative predation intensity? An empirical test using mummichogs and grass shrimp. Mar Ecol Prog Ser 198:181-190

Kraufvelin P (1999) Baltic hard bottom mesocosms unplugged: replicability, repeatability and ecological realism examined by non-parametric multivariate techniques. J Exp Mar Biol Ecol 240:229-258

Lewis SM (1986) The role of herbivorous fishes in the organization of a Caribbean reef community. Ecol Monogr 56: $183-200$

Peterson CH, Black R (1994) An experimentalist's challenge: when artifacts of intervention interact with treatments. Mar Ecol Prog Ser 111:289-297

Pile AJ, Lipcius RN, van Montfrans J, Orth RJ (1996) Densitydependent settler-recruit-juvenile relationships in blue crabs. Ecol Monogr 66:277-300

Shulman MJ (1985) Recruitment of coral reef fishes: effects of distribution of predators and shelter. Ecology 66: 1056-1066

Steneck RS (1983) Quantifying herbivory on coral reefs: just scratching the surface and biting off more than we can chew. In: Reaka ML (ed) The ecology of deep and shallow coral reefs. NOAA Symp Ser Undersea Res, Vol 3, Silver Spring, MD, p 103-111

Zimmer-Faust RK, Fielder DR, Heck KL Jr, Coen LD, Morgan SG (1994) Effects of tethering on predatory escape by juvenile blue crabs. Mar Ecol Prog Ser 111:299-303 